\title{
(- OPEN ACCESS \\ Usefulness of new flex-rigid pleuroscopy in the diagnosis of malignant pleural mesothelioma
}

\author{
Satoru Ishii, ${ }^{1}$ Yoshiki Ishii, ${ }^{2}$ Takayuki Kaburagi, ${ }^{3}$ Takashi Nakano ${ }^{4}$
}

'Department of Respiratory Medicine, National Center for Global Health and Medicine, Shinjuku-ku, Japan

${ }^{2}$ Department of Pulmonary Medicine and Clinical

Immunology, Dokkyo Medical University School of Medicine, Mibu, Japan

${ }^{3}$ Respiratory Medicine, Ibaraki Prefectural Central Hospital, Kasama, Japan

${ }^{4}$ Respiratory Medicine, Otemae Hospital, Osaka, Japan

Correspondence to Dr Satoru Ishii,

satishii@hosp.ncgm.go.jp

Accepted 15 December 2018

\section{DESCRIPTION}

An 83 -year-old woman presented with dyspnoea. Chest X-ray showed right-sided pleural effusion, which was confirmed by chest CT scans on admission. A nodular shadow was also visualised in the front part of the chest (figure 1). ${ }^{18} \mathrm{~F}$-Fluorodeoxyglucose-positron emission tomography (FDG-PET) showed a maximum standardised uptake value of 10.5 in the nodule. Thoracentesis showed that the effusion was exudative, while cytodiagnosis was negative. Hence, pleuroscopy under local anaesthesia was performed to aid diagnosis.

We enforced flex-rigid pleuroscopy using the LTF-Y0032 (Olympus, Japan). The LTF-Y0032 enables observations with a maximum angle of curvature of $180^{\circ}$, allowing visualisation of the area near the insertion site of the pleuroscope (figure 2). Pleuroscopy revealed the mass near the insertion site of the pleuroscope. Then, biopsy forceps were inserted and a sufficient amount of tissue was successfully harvested for immunohistochemistry. The pathological evaluation demonstrated that the tumour was malignant pleural mesothelioma (biphasic type). We report the first case in which the LTF-Y0032, a new pleuroscopy, was used for diagnosis. Conventional fibrescopes (the LTF-240 and LTF-260) have a maximum angle of curvature of $160^{\circ}$ and this angle is further reduced by the insertion of biopsy forceps. However, the new pleuroscope enables observations to be made up to an angle of $180^{\circ}$.

Since malignant mesothelioma is difficult to diagnose, requiring harvesting of a sufficient amount of tissue. ${ }^{1}$ In the present case, malignant cells were also detected in biopsy specimens from small protuberances at other sites, although the amount collected was insufficient for immunostaining. The new pleuroscope
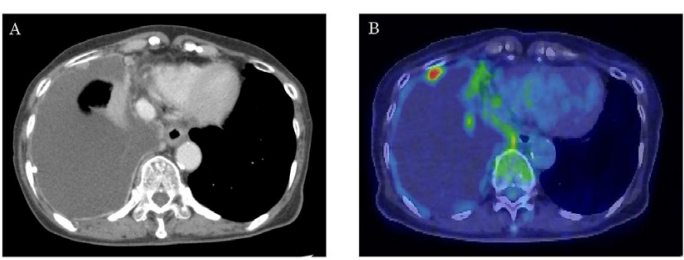

Figure 1 (A) Chest CT scans on admission showing a right pleural effusion. $A$ nodular shadow is seen in the front. (B) ${ }^{18} \mathrm{~F}$-Fluorodeoxyglucose-positron emission tomography showed a maximum standardised uptake value of 10.5 in the nodule.

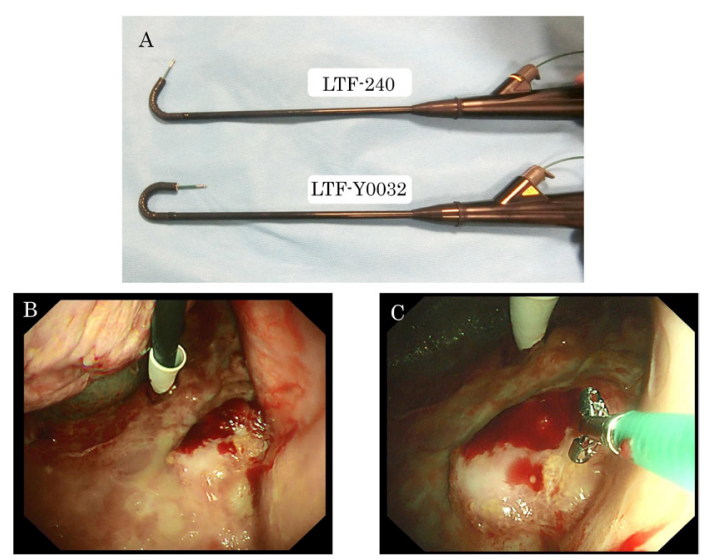

Figure 2 (A) Conventional pleuroscope (LTF-240) with the inserted biopsy forceps directed fully upward (upper). New pleuroscope (LTF-Y0032) with the inserted biopsy forceps directed fully upward (lower). (B) The LTF-Y0032 is capable of observations at a maximum curvature of $180^{\circ}$ when directed fully upward, enabling the observation of masses at the introducer insertion site and close to the introducer. (C) Biopsy forceps were inserted and moved near the mass, which was close to the introducer.

enabled a sufficient amount of the tissue sample to be biopsied from a mass close to the introducer insertion site.

Although the diagnostic yield of pleuroscopy under local anaesthesia for pleural effusion of unknown origin is high at $92.6 \%$, the diagnosis of malignant mesothelioma may be difficult in some cases. ${ }^{2}$ It has recently been reported that cryobiopsy is useful for the diagnosis of sarcomatoid-type malignant mesothelioma. ${ }^{3}$ Cryobiopsy is useful in thickened pleura including the adipose tissue.

The internal diameter of the LTF-Y0032 pleuroscope is $3.0 \mathrm{~mm}$, compared with the diameter of $2.8 \mathrm{~mm}$ of existing pleuroscope. New pleuroscopy allows the use of both 1.9 and $2.4 \mathrm{~mm}$ cryoprobes. A cryoprobe is stiffer than conventional biopsy forceps and it is difficult to attain a full $180^{\circ}$ range. Currently, it is not clear whether conventional biopsy forceps or cryobiopsy provide a higher diagnostic yield when diagnosing malignant pleural mesothelioma. This will need to be evaluated in the future.

Use of this new pleuroscope promises to increase diagnostic yield under local anaesthesia for pleural effusion of unknown origin. 


\section{Learning points}

The new pleuroscope (LTF-Y0032) enables observations to be made up to an angle of $180^{\circ}$.

- The internal diameter of the LTF-Y0032 pleuroscope is 3.0 $\mathrm{mm}$, compared with the diameter of $2.8 \mathrm{~mm}$ of existing pleuroscope.

Contributors SI: was involved in the pleuroscopic biopsy and writing up of the manuscript. SI, YI, TK and TN: development of the LTF-Y0032 fiberscope.

Funding The authors have not declared a specific grant for this research from any funding agency in the public, commercial or not-for-profit sectors.

Competing interests None declared.
Patient consent Obtained.

Provenance and peer review Not commissioned; externally peer reviewed.

Open access This is an open access article distributed in accordance with the Creative Commons Attribution Non Commercial (CC BY-NC 4.0) license, which permits others to distribute, remix, adapt, build upon this work non-commercially, and license their derivative works on different terms, provided the original work is properly cited and the use is non-commercial. See: http://creativecommons.org/ licenses/by-nc/4.0/

\section{REFERENCES}

1 Michaud G, Berkowitz DM, Ernst A. Pleuroscopy for diagnosis and therapy for pleural effusions. Chest 2010;138:1242-6.

2 Wang XJ, Yang Y, Wang Z, et al. Efficacy and safety of diagnostic thoracoscopy in undiagnosed pleural effusions. Respiration 2015:90:251-5.

3 Chan HP, Liew MF, Seet JE, et al. Use of cryobiopsy during pleuroscopy for diagnosis of sarcomatoid malignant mesothelioma. Thorax 2017;72:193-5.

Copyright 2018 BMJ Publishing Group. All rights reserved. For permission to reuse any of this content visit https://www.bmj.com/company/products-services/rights-and-licensing/permissions/

BMJ Case Report Fellows may re-use this article for personal use and teaching without any further permission.

Become a Fellow of BMJ Case Reports today and you can:

- Submit as many cases as you like

- Enjoy fast sympathetic peer review and rapid publication of accepted articles

- Access all the published articles

Re-use any of the published material for personal use and teaching without further permission

For information on Institutional Fellowships contact consortiasales@bmjgroup.com

Visit casereports.bmj.com for more articles like this and to become a Fellow 